Tourism Research Journal

E-ISSN: 2598-9839

2020, Vol. 4 No. 2

\title{
Analysis of Homestay Criteria Compliance in Tourist Village According to The Visitors' Perception
}

\author{
Pusparani \\ Sekolah Tinggi Pariwisata Trisakti \\ pusparani@stptrisakti.ac.id
}

\begin{abstract}
Abstract The development of tourism villages cannot be separated from the homestay existence as accommodation. As part of the tourism amenities, homestay's comfort is important. It's caused that the tourism activities products are intangible. Homestay feasibility will determine how long the visitor will allocate their time to stay in the tourist village. ASEAN Tourism in 2016 has published the standard homestay criteria, which contain nine variables standard criteria. The study aims to determine how far the homestay criteria' suitability in the tourism village according to visitors' perceptions in line with the ASEAN Tourism standard criteria established. Besides that, they also provide input to stakeholders to provide and manage the homestay properly and meet these criteria. This method is done by measuring six variables that are directly felt by visitors. The results show that among the six variables surveyed, five variables showed a level of conformity above $80 \%$, and 1 variable in the level of $50 \%$ suitability.
\end{abstract}

Keywords: criteria, tourist village, homestay 


\section{A. Introduction}

The tourism sector has a strategic role in national economic development, contributes greatly to creating jobs, improving people's welfare, and also contributing to foreign exchange for the country. The success of tourism development is generally measured using the parameter of the number of tourist visits. In order to increase the number of tourists, efforts should be made, among the others, the fulfillment of the tourists need for facilities such as hotels, restaurants, transportation, travel agents, and other entertainment types. As a tourism destination, a tourist village is formed by a series of product components, areas and images or characteristics of attractions that are an important focus in tourism development, especially in developing comparative advantages and competitive advantages in competing to attract regional and international tourist markets. To achieve this goal, it is necessary to understand what factors influence tourists in making decisions when visiting a tourist object or destination. By knowing these factors, it is hoped that it will increase the number of tourist visits, repeat visits (repeaters) and the length of stay of tourists, and increase tourist spending in a destination, which will ultimately improve the welfare of the community.

Tourist attractions and amenities are the main basis for tourism attraction. For this reason, planning for amenities is very important. It is caused the planning to systematically prepare facilities and infrastructure to meet the needs of tourists while visiting the site. The visitors or tourists are the main focus in receiving attention because visitors have an important role in supporting tourist village destinations' success. Tourism products are intangible products, which means the visitors will feel impressed if the service provided of these products, really brings an unforgettable impression. By understanding visitors' needs and desires, it is hoped that the tourism village will be visited by many tourists both from within the country and abroad. One of the needs that must be understood in providing tourism village facilities is hostelry (homestay). According to Chairunisa (2015), a homestay is a community house that tourists can board or rent to get to know the community's language, culture, daily life, and local wisdom. Homestay has an important role in supporting regional tourism development, improving the community's economy, and community participation in maintaining natural and cultural resources owned as tourist attractions. Lama, M (2013) stated that homestays have effectively become a tool to support rural communities' economic and natural resource sustainability in Nepal. Bhan and Singh (2014) stated that the existence of homestay can be a supporting poverty alleviation program and maintain the existence of natural resources where local residents live.

In Indonesia, the existence of a homestay is supported by the government, it's proved that homestay is be a program listed in the vision and mission of the Ministry of Tourism of the Republic of Indonesia. A lot target of 
Analysis of Homestay Criteria Compliance in Tourist Village According to The Visitor's Perception

homestay will be launched by the government, in 2019 the number of new homestays is 100,000 (Tempo.co.id).

As part of the Tourism Village complementary, homestays are the part of tourism amenities that combine with affordable accommodation and authentic local culture as tourism attractions preserve local traditional architecture. Staying at a homestay is considered to add experience and information about the local community's activities and habits. Tourists can learn about the local community's living culture through direct interactions between tourists and local people.

Homestay as a part of tourism amenities will be a leisure and comfortable place to live for tourists if homestay management is carried out according to international standards. In 2016 ASEAN Tourism has issued a Guidebook on homestay criteria entitled ASEAN Homestay Standard. The book contains several criteria that have to be fulfilled in building a homestay. By issuing the standard criteria of homestay, it is hoped that homestay in Indonesia's tourist villages can comply these standard criteria. The problem often arises and faced by a tourism village destination is the readiness in the receiving visitors (tourists). It is caused not all of the villagers have a suitable house to be used as a homestay who meets the homestay standards criteria. The unavailability of proper lodging facilities could impact the visitors who come will be stopping their intention to stay longer in that village. A further impact is that visitors will discourage visiting tourist villages, especially for the village located far from city centers. Besides the physical readiness requirement of a house, the home owner's readiness as a home operator also very important such as hospitality, politeness, spirit of service, and awareness of tourism.

Lodging facilities (homestay) is one of the factors that determine whether tourists decide to stay longer in a tourist destination. Homestay management training is one of the activities that is always carried out to increase the capacity of tourist villages. For example, when mentoring Cipasung village to be a tourism village, one of the trainings carried out was homestay management (Rachman, A. et.al. 2019). Likewise, tourism village in increasing its capacity still needed to carry out homestay training, as being done in Cikolelet village (Suprina, R. and Rachman, A. 2019) To find out how far the homestay in a tourist village has met the standard criteria of homestay published by ASEAN Tourism, this research with the title "Analysis of Homestay Criteria Compliance in Tourist Village According to The Visitors' Perception" was conducted.

\section{B. Literature Review}

\section{Tourism Village}

According to Inskeep (1991), a tourism village stated, "Village Tourism, where small groups of tourists stay in or near traditional, often remote villages and learn about village life and the local environment." Meanwhile, according to Nurhayati and Wiendu (1993) a tourism village is the integration of attractions, accommodation and supporting facilities presented in the form of community

Tourism Research Journal, Volume 4 (2), 2020 
Analysis of Homestay Criteria Compliance in Tourist Village According to The Visitor's Perception

life structure that is integrated with the norms and traditions. The development of a tourist village has a positive impact on economic, social and environmental aspects for rural communities as local communities, so that the development of this tourist village is welcomed by the surrounding community (Festivalia et al., 2019).

\section{Tourism Product Components}

Tourism Product Components, tourism products consist of several interrelated components, namely tourist attraction, accessibility, supporting facilities (amenity) and ancillary organizations. The priority that can be done is to develop tourism villages and maintain attractiveness by preparing tour packages, and structuring the area (Swantari and Wicaksono, 2020).

1. Tourism Attraction.

It is the main product of a destination, can be in the form of natural, cultural, or artificial, as well as activities that are important to a tourist attraction because they relate to what to see and what to do.

2. Accessibility.

Factors that support tourists' convenience to reach the tourist village, such as road signs, availability of transportation modes, and road conditions to the village.

3. Support facilities.

In the form of accommodation and other facilities, accommodation is a place where tourists or people who are traveling or visiting a place need facilities to rest or stay overnight. Accommodation in a Tourism Village should be in the form of an original resident's house or a building whose design can mirror the village's culture. Accommodation in tourist villages can be in the form of: camping ground, villas or homestays

4. Supporting organizations/institutions.

The availability of an organization or people who take care of the tourist village. Organization is very important in the management of a tourist village, because with a good organization, the management of the tourism village will also be good (Antara and Arida, 2015).

\section{Homestay Criteria}

Temporary accommodation needed by tourists or visitors is very much needed in the form of a homestay or camping when they are in a tourist village. In this case, some standards must be considered a benchmark in determining whether a house can be categorized as a homestay. Currently, what happens a lot is that many homestays are not following the standard criteria for determining a homestay. In the end, visitors or tourists will not achieve the comfort expected.

ASEAN Tourism (2016) has issued nine criteria that must be met in the provision of homestay facilities. By publishing the homestay standard criteria intended to develop comprehensiveness and create a quality of visitor experience

Tourism Research Journal, Volume 4 (2), 2020 
by displaying in a neat, safe, and attractive rural resources manner. ASEAN Tourism has nine standard criteria, are as follow householder, logging, activities, management, location, cleanliness principles, safety \& security, marketing and sustainability. The nine criteria of homestay standard describes as follows (cited from ASEAN Homestay Standard):

1. Host

a. The Village and Community

1) Minimum there are five amount number registered homestay provider to reflect community involvement and cohesion within the village .

2) The location of the homestay close to the attractions of tourism in the surrounding areas.

3) The village destination has to proven good track record in community organization and beautiful natural resources.

4) The village's destination have authentic and original activities.

b. Homestay Provider

1) The homestay owner must be good habit and attitude.

2) Condition of the homestay owner must be in a good health.

3) The registered homestay provider have to get a basic course of homestay.

2. Accommodation

a. The House

1) The house structures must be strong.

2) The architecture of homestay shall be authentic and original, showing the local architecture and design.

3) Available separated bedroom(s) for guest.

4) Minimum one bathroom separated for the guest.

5) The readiness of electricity supply.

6) Available clean water supply, all the day.

b. The Bedroom

1) Basic facilities supported in bedroom.

2) Only four rooms available in one homestay for guest.

3) Standard and appropriate beds are provided, such as single beds and double beds with comfortable mattresses and pillows.

4) The bedroom's window should be fitted with mosquitoes frame.

5) Every new guest should get new bed linen facilities.

c. The Toilet/Bathroom

1) Every homestay must be provided with separated bathroom/ toilet for guest.

2) Toilet and bathroom doors are equipped with a lock and lighting.

3. Activities

3) Clean water supply at any time.

a. Activities Community in Village

Tourism Research Journal, Volume 4 (2), 2020 
Activities of community in the village should optimally and represent the local resources such as local culture and heritage, enterprises and natural resources

Interactive interaction between the local community and the guest should be encouraged.

b. Surrounding Activities

1) Tour program should be integrated with the homestay functioning as a base camp.

2) Other villages were involved in adding a variety of activities to obtain a multiplier effect.

c. Authenticity

1) Authentication values must be maintained to represent different identities.

2) Involve guests in communal activities in the performing arts and other activities.

3) Forming cultural groups and associations to preserve local performing arts.

4. Management

a. Leadership

Organizational leaders must be respected and authoritative people.

b. Organization

1) have a systematic structure with clear rules and responsibilities.

2) The empowerment of the local women and youths facilitated by organisation.

3) The set up of organization is blessed by the village management.

c. Database

1) Homestay Operator Database

The database of the homestay operators should be established.

2) Guest Database

a) Keep a record of the guest database

b) Create a reservation and registration system.

c) The guest database also record comments, complaints, and suggestions from guests.

3) Product Database

Updating the inventory of tourism objects in the village and the surrounding areas.

d. Capacity Building and Training

1) The homestay organisation shall make an SOP guidelines covering the following aspects:
a) Salutation
b) Reservation management and finance administration
c) Housekeeping
d) Public relation

Tourism Research Journal, Volume 4 (2), 2020 
Analysis of Homestay Criteria Compliance in Tourist Village

According to The Visitor's Perception

e) Tours planning and packaging of the tour program

f) Marketing, sales and promotion

g) Storytelling and interpretation skills (local tour guide)

2) To educate the owner of the homestay, village organization shall work together with institutions, university, or tourism village community

e. Collaboration

Cooperating with homestays and other travel agencies such as tour operators and collaborating with hospitality to develop tour packages and increase marketing activities. In collaboration with international and national tourism organizations to seek training, funding, marketing, promotion, and other technical advice. Together with non-governmental organizations (NGOs) to develop joint programs in environmental and cultural preservation. Collaboration with universities and institutions to increase human resource capacity building.

5. Location (Accessibility)

a. The location of the homestay can be reached with any mode of transportation.

b. The homestay location provided with clear direction and signage .

6. Hygiene and Cleanliness

a. House

1) All of the homestay facilities must be kept clean.

2) Regularly the floors must be clean and free from stains and spills.

3) All equipment in the bathroom must be cleaned regularly.

4) Using disinfectants to keep free from germs and viruses.

5) Provided with clean toiletries.

b. Surrounding Compound

1) The area should be clean.

2) Free from mosquito breeding sites

3) Arrangement of village and landscape using local plants and maintaining regularly

c. Food Preparation

1) kitchen conditions must be good and clean, and well ventilated.

2) Plates, glasses and mugs, etc. shall be in good condition.

3) The person involved in food preparation always have good personal hygiene.

4) Food ingredients used in food preparation must be fresh and get from the local market.

5) Food served in a good performance.

6) Only serve safe drinking water for guests.

7. Safety and Security

a. Safety Training

Person in charge of who controls first aid in an accident.

b. Safety Features for Facilities Activities

Tourism Research Journal, Volume 4 (2), 2020 
1) at least two safety personnel accompanying guests

2) Provided safety equipment every any water-based activity

3) Any physical facilities shall have safety features.

4) Well marked and signposted for trails and trekking routes

c. Briefing every aspect of security

1) briefing on safety aspects for guest in taking part of homestay activity

2) On safety guidelines and tips for guests, provide the leaflets.

3) required to register the guest name and contact number for recording purposes.

4) Standard Operating Procedure (SOP) Implementation.

d. Emergency Rescue and Evacuation

1) During activities, guests accompanied someone who in charge of safety.

2) During accompanied the guest, persons in charge of safety bring communication tools.

3) Guests are provided with insurance.

4) All the guests shall obey safety procedure.

8. Marketing and Promotion

a. Promotion Activities

1) To suit their needs and expectations, determine the target market for prospective customers and plan a tour program.

2) To differentiate it from the other homestay, determine what the prospect customer needs and want (USP) of the village.

3) Avoid ambiguity in making matters relating to promotional activities.

4) Cooperation with stake holder in sales activities.

b. Partnership with Corporate hospitality

1) Close cooperation with tour operators

2) Cooperate with tourism stakeholders in forming tourist village.

c. Web Marketing

1) The village management should develop an online reservation to accommodate customer to make a booking .

2) Updating and maintaining promotional information online.

9. Sustainability Principles

Economic Sustainability

a. Employment

1) Prioritize of the village community in recruiting employment the staff.

2) Motivated local communities by giving a rewarding.

3) Micro finance provided in deserving local business .

b. Purchasing

1) Prioritizing purchase of local products .

2) Drive and direct the guests to buy handicrafts in the sales area.

c. Local Product/Attraction

1) To nearby markets promote local festivals and visits.

Tourism Research Journal, Volume 4 (2), 2020 
2) Introducing culture heritage, indigenous food, and historical sites to the guestt.

d. Environmental Sustainability

1) In sensitive natural and cultural environments, the village organization must be careful. The sustainability of the environment can be maintained.

2) Minimizing activities on-site could reduce exploitation flora and fauna.

3) Organize litter clean ups with guests and adopt nearby beach, forest or river.

4) Develop a code of conduct (or dos and don'ts) when interaction with wildlife.

5) Awareness of biodiversity conservation for the local community.

6) Tourist village facilities are environmentally friendly.

e. Sociocultural Sustainability

1) At the homestay centre and common areas, set up information corners and cultural displays

2) The guests who come must know everything related to the local community's customs, attitudes, and behavior.

3) To give the knowledge how important to preserve community culture.

4) Campaign against sexual exploitation and drugs.

\section{Research Methodology}

This research was conducted as a descriptive analysis study to test the suitability of homestays' standard criteria in tourist villages. This research's objects are tourists who have visited and spent the night at a homestay in a tourist village. This research basically determines how far the compliance of 6 variables of the standard criteria published by ASEAN Tourism meets with homestay in tourist village. The six variables used in this study is related directly with visitors as homestay users. The three remaining variables were not carried out in this survey because they are related to the homestay provider. The sampling method using in this study is purposive sampling.

The sample in this study were tourists (visitors) who had visited and spent the night at a homestay in a tourist village. The primary data used in this study was obtained from the respondent's answers of the questionnaires. Secondary data comes from literature studies, research results, final assignments, and articles on the internet and mass media. The technique of collecting data uses a survey method by distributing questionnaires to respondents who have met specific criteria to answer questions built based on 6 variables and several existing indicators. The questionnaire was prepared using variables and indicators in the ASEAN Homestay Standard. The question is a closed question in which the respondent is given two choices to answer yes and no.

Tourism Research Journal, Volume 4 (2), 2020 
The analysis technique used is the Conformity Index calculation. Quantitative analysis is used to calculate the Conformity Index (IK). The tourism suitability analysis uses a suitability matrix arranged based on each variable's importance to support the suitability of the homestay criteria. The following is a formula for analyzing the suitability of the homestay criteria:

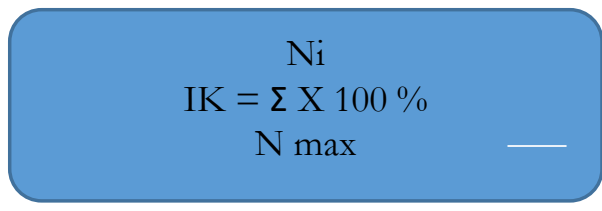

IK : Indeks Kesesuaian (Comformity Index)

$\mathrm{Ni}$ : Nilai variabel ke-i (Variable value)

Nmax : Nilai maksimum dari variabel (Maximum value of variable)

Furthermore, the class compilation was arranged based on the questionnaire's answering results in accordance with existing variables. In this study, the homestay suitability class is divided into three suitability classes, namely: Appropriate (S1), Unsuitable (S2) as in the matrix below.

Table 1. The Homestay Suitability Class

\begin{tabular}{|l|l|l|}
\hline Category & Conformity Index & Information \\
\hline S1 & $80 \%-100 \%$ & Accordingly \\
\hline S2 & $<80$ & Not Accordingly \\
\hline
\end{tabular}

\section{Result}

Based on the 74 respondents who answered the questionnaire, if it is classified based on the tourist villages visited, there are 14 tourist destinations. The following is a recapitulation of tourist villages that have been visited, presented in table 2

Table 2. List of Tourism Villages and Number of Respondents

\begin{tabular}{|c|l|c|}
\hline No & Name of Tourist Village & Respondents Amount \\
\hline 1 & Cibuntu & 36 \\
\hline 2 & Cikolet & 1 \\
\hline 3 & Cinangneng & 1 \\
\hline 4 & Cipasung & 10 \\
\hline 5 & Gua Pindul & 7 \\
\hline 6 & Jagara & 15 \\
\hline 7 & Sakerta Timur & 1 \\
\hline 8 & Sawarna & 2 \\
\hline 9 & Waduk Darma Kuningan & 1 \\
\hline 10 & Nglanggeran & \\
\hline
\end{tabular}

Tourism Research Journal, Volume 4 (2), 2020 
Analysis of Homestay Criteria Compliance in Tourist Village According to The Visitor's Perception

\begin{tabular}{|r|l|c|}
\hline 11 & Pujon Kidul & 1 \\
\hline 12 & Kampung Naga & 1 \\
\hline 13 & Kampung Ragam Warna Kendal & 1 \\
\hline 14 & Sembalun & 1 \\
\hline \multicolumn{2}{r|}{ Total } \\
\hline
\end{tabular}

From the table, it can be seen that there are three respondents who have visited more than one tourist village. 1 respondent has visited 4 tourist villages and 2 respondents have visited 2 tourist villages.

Based on the respondents' 6 homestay suitability variables, the following table is an overview of the results.

Table 3. Recapitulation of Data Tabulation Results Based on 6 Homestay Suitability Variables

\begin{tabular}{|c|c|c|c|c|c|}
\hline Variable & Indicator & Sub Indicator & Yes & No & Abstain \\
\hline \multirow[t]{3}{*}{ Host } & \multirow[t]{2}{*}{$\begin{array}{l}\text { Village and } \\
\text { Community }\end{array}$} & $\begin{array}{l}\text { There are a minimum of } 5 \\
\text { homestay providers }\end{array}$ & 65 & 8 & 1 \\
\hline & & $\begin{array}{lcr}\text { Lokasi } & \text { homestay } & \text { dekat } \\
\text { dengan } & \text { tempat } & \text { wisata } \\
\text { budaya } & & \\
\end{array}$ & 70 & 4 & \\
\hline & $\begin{array}{l}\text { Homestay } \\
\text { Provider }\end{array}$ & $\begin{array}{l}\text { Generally healthy and not } \\
\text { affected by disease }\end{array}$ & 73 & 1 & \\
\hline \multirow[t]{6}{*}{$\begin{array}{l}\text { Accommo } \\
\text { dation }\end{array}$} & \multirow[t]{4}{*}{ The House } & $\begin{array}{l}\text { The design and building of } \\
\text { the house reflects the local } \\
\text { identity }\end{array}$ & 59 & 15 & \\
\hline & & $\begin{array}{l}\text { The homestay owner } \\
\text { provides a separate } \\
\text { bedroom from other rooms }\end{array}$ & 72 & 2 & \\
\hline & & $\begin{array}{l}\text { Homestay owners provide } \\
\text { at least one bathroom for } \\
\text { guests }\end{array}$ & 57 & 17 & \\
\hline & & $\begin{array}{l}\text { The homestay owner } \\
\text { provides a sufficient supply } \\
\text { of clean water and is } \\
\text { available at all times }\end{array}$ & 71 & 2 & 1 \\
\hline & \multirow[t]{2}{*}{ The Bedroom } & $\begin{array}{l}\text { There are basic amenities } \\
\text { and furniture in the bedroom }\end{array}$ & 72 & 2 & \\
\hline & & $\begin{array}{l}\text { Standard size bed with } \\
\text { comfortable mattress and } \\
\text { pillows }\end{array}$ & 70 & 3 & 1 \\
\hline
\end{tabular}

Tourism Research Journal, Volume 4 (2), 2020 
Analysis of Homestay Criteria Compliance in Tourist Village According to The Visitor's Perception

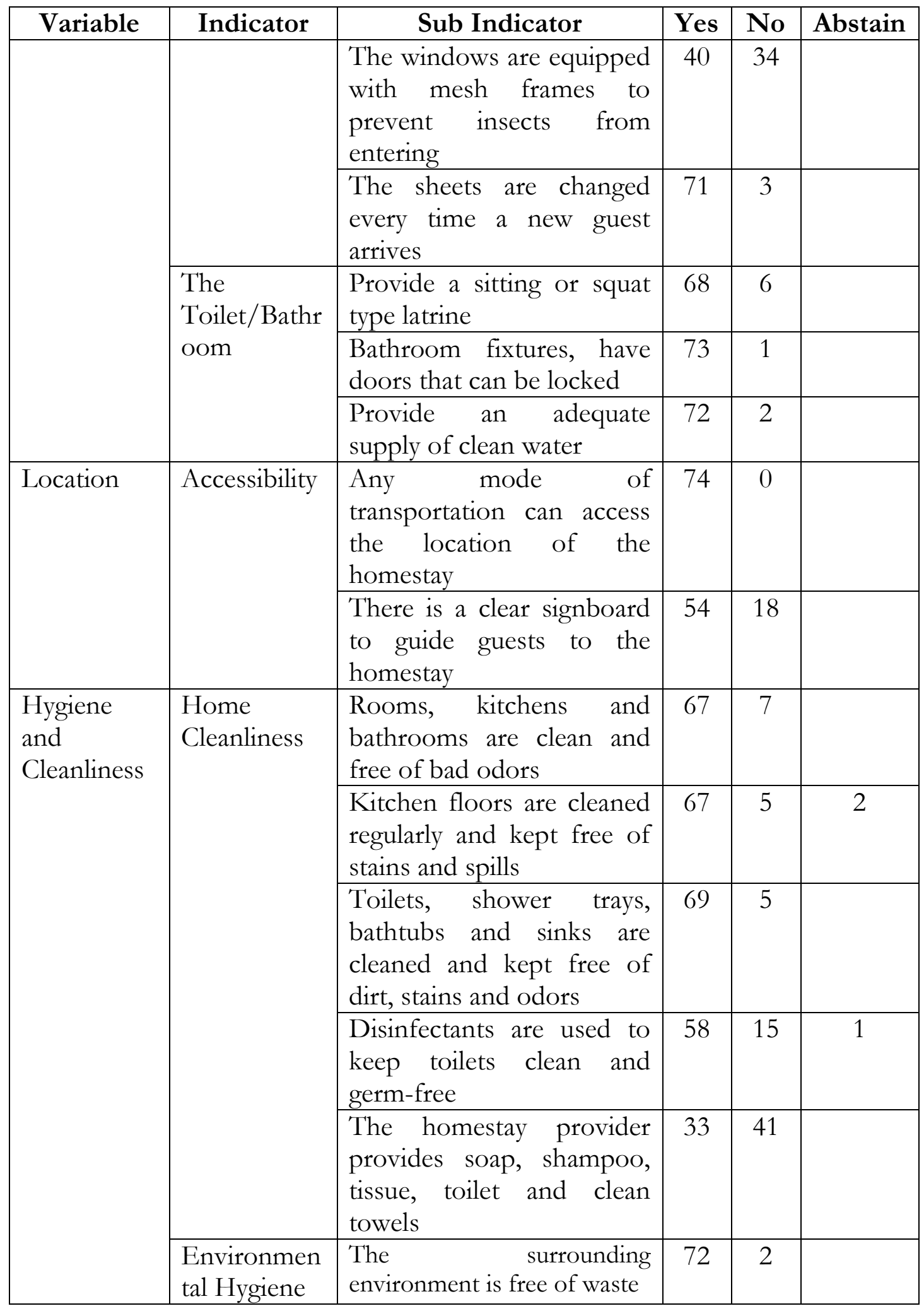

Tourism Research Journal, Volume 4 (2), 2020 
Analysis of Homestay Criteria Compliance in Tourist Village According to The Visitor's Perception

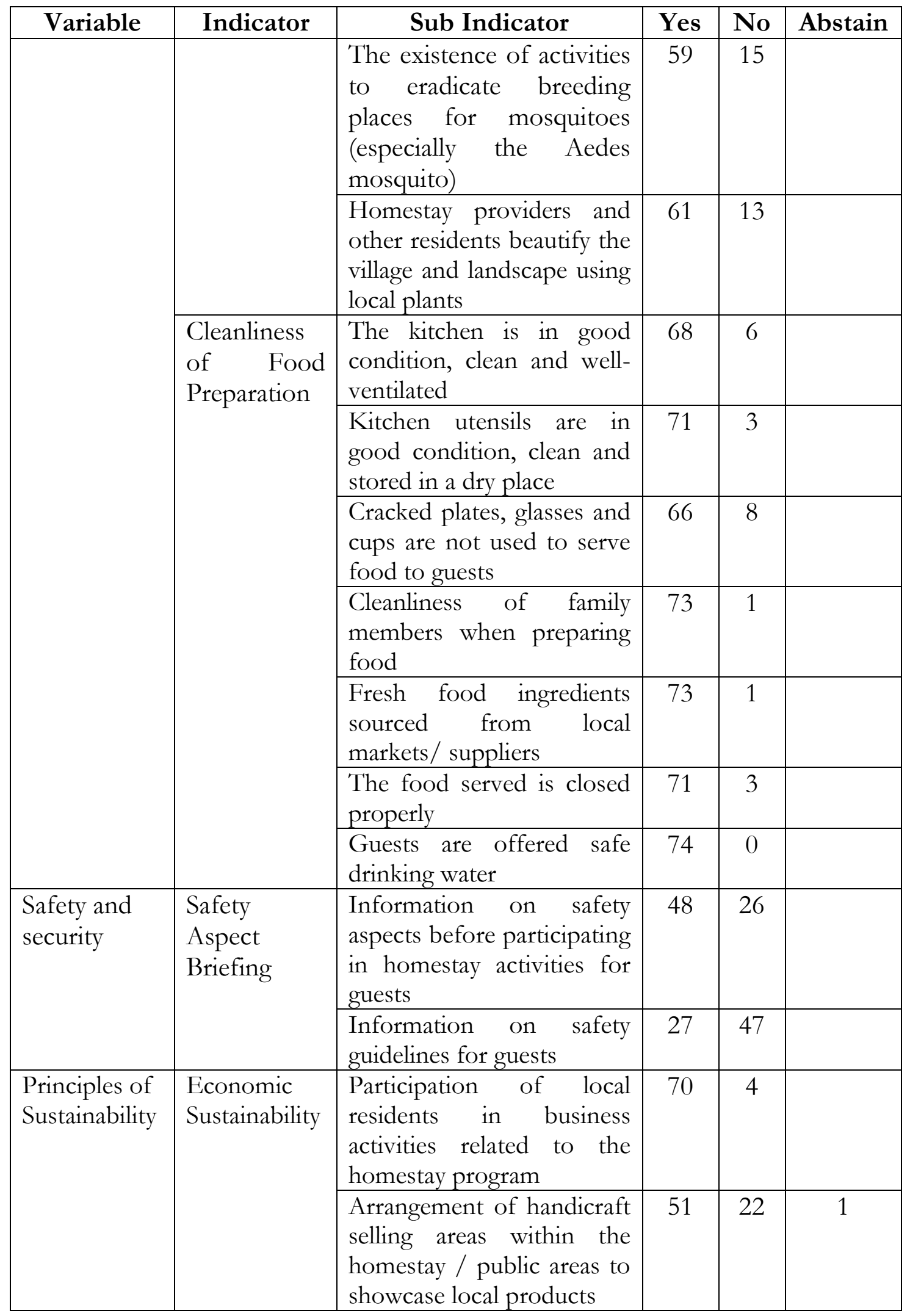

Tourism Research Journal, Volume 4 (2), 2020 
Analysis of Homestay Criteria Compliance in Tourist Village According to The Visitor's Perception

\begin{tabular}{|c|c|c|c|c|c|}
\hline Variable & Indicator & Sub Indicator & Yes & No & Abstain \\
\hline & & $\begin{array}{l}\text { There are festival } \\
\text { promotions and visits to } \\
\text { nearby local markets }\end{array}$ & 52 & 22 & \\
\hline & & $\begin{array}{l}\text { There are areas that offer } \\
\text { traditional crafts, food, and } \\
\text { host cultural events and } \\
\text { performances for guests }\end{array}$ & 65 & 9 & \\
\hline & $\begin{array}{l}\text { Environmental } \\
\text { Sustainability }\end{array}$ & $\begin{array}{l}\text { Local community } \\
\text { knowledge about the } \\
\text { importance of preserving } \\
\text { biodiversity }\end{array}$ & 65 & 7 & 2 \\
\hline & & $\begin{array}{l}\text { Communities understand } \\
\text { the design and } \\
\text { construction of eco- } \\
\text { friendly tourism facilities } \\
\text { and services }\end{array}$ & 68 & 6 & \\
\hline & $\begin{array}{l}\text { Social and } \\
\text { Cultural } \\
\text { Sustainability }\end{array}$ & $\begin{array}{l}\text { There is an information } \\
\text { center and cultural display } \\
\text { in the homestay center and } \\
\text { common areas }\end{array}$ & 54 & 20 & \\
\hline & & $\begin{array}{l}\text { There is information on } \\
\text { the need to respect local } \\
\text { customs and courteous } \\
\text { behavior }\end{array}$ & 64 & 10 & \\
\hline
\end{tabular}

Primary data that have been collected, continuing with statistically processed. After the data processed, further classified into the suitability matrix to determine the suitability class and the result is presented in the following table.

Table 4. Matching Results of Six Variables Standard Criteria Homestay

\begin{tabular}{|l|c|c|c|}
\hline \multicolumn{1}{|c|}{ Variable } & $\begin{array}{c}\text { Conformity } \\
\text { index }\end{array}$ & Conformity & Information \\
\hline Host & $94 \%$ & S1 & Accordance \\
\hline Accommodation & $89 \%$ & S1 & Accordance \\
\hline Location & $88 \%$ & S1 & Accordance \\
\hline Hygiene and Cleanliness & $89 \%$ & S1 & Accordance \\
\hline Safety and security & $50 \%$ & S2 & No Accordance \\
\hline Principles of Sustainability & $83 \%$ & S1 & Accordance \\
\hline
\end{tabular}

Tourism Research Journal, Volume 4 (2), 2020 
Analysis of Homestay Criteria Compliance in Tourist Village

According to The Visitor's Perception

\section{E. Discussion}

The tourism industry is a service industry that combines products and services. The services were offered to other parties are basically intangible and no result in any ownership. The function of a homestay as a place for overnight or stay consumers who traveling on tour, service is a very important aspect that should be considered by homestay providers. Service quality is centered on fulfilling needs and wants as well as the accuracy of delivery to meet customer satisfaction. Besides a good service quality, facilities also play a role in attracting consumers. Facilities are tools to make it easier for consumers to carry out an activity. Facilities are one of the consumers' consideration in making choices. The facilities more complete provided by the homestay provider, it can make the customers more satisfied services will get and they will continue to choose those homestay as their priority choice, based on the perception they get on the available facilities.

A tourist village as a tourist destination ideally has accommodation facilities in the form of a temporary residence to stay while tourists visit in the tourist village. A house as a place to temporarily stay in a tourist village or commonly known as a homestay is supporting a tourism product where the tourists will come. With the existence of decent and appropriate homestay, it is expected that visitors would stay longer and are expected to spend their money in the village. A homestay function is not only as a place to spend the night but also as a functional place to rest or multifunctional, for example, as function as eat together, pray, toilets, etc. Lack of understanding standardization of service in homestay management and visitor satisfaction, the economic support for the community will be difficult to achieve as one of tourism development purposes. Based on the survey results, the data statistically shows that the highest suitability index is for the host variable at $94 \%$, followed by the accommodation and hygiene and cleanliness variables at $89 \%$, then for the location variable for $88 \%$, for the sustainability principle variable for $83 \%$. According to respondents, the safety and security variables were not included in the appropriate category, namely the conformity index was still $50 \%$.

The fulfillment of the homestay criteria cannot be separated from the involvement of stakeholders such as government, community, education institutions and tour operators. The government's role is to disseminate policies, facilitating and providing guidance homestay standard criteria for provider and tourism awareness group (Pokdarwis) also conducting training. Meanwhile, educational institutions as a source of knowledge are expected to provide additional hospitality knowledge in the hence the quality of services Visitors' get will be increased, besides that also provide education training homestay standard. The communities who are members of the Sadar Wisata group (POKDARWIS) and youth organizations in tourism villages are expected to assist the implementation of educational institutions' training. The involvement of tour operators is also important because it will help homestay providers in selling

Tourism Research Journal, Volume 4 (2), 2020 
tourism product. The collaboration of the government, educational institutions, communities, and tour operators synergic in managing homestay's standard compliance will ultimately contribute to the district's socio-economic.

A tourist village that already has several homestays, but in their implementation there are still some problems, it needs more intensive guidance from stakeholders, so that the purpose of developing a tourist village can be achieved.

\section{F. Conclusion}

The survey results show that five variables, namely Host, Location, Accommodation, Hygiene, and Cleanliness as well as the Principle of Sustainability according to the perception of visitors still have a Conformity Index above $80 \%$, and one variable, namely the Safety and Security Index of Conformity variables below $80 \%$.

Changing the function of an ordinary residence to a homestay requires the following steps:

1. Change the mindset of a residential owner to become an operator of a guest house for visitors.

2. To be able to create an inpatient house or homestay that fits the ideal criteria, intensive counseling and training are required for prospective homestay owners.

3. After the training, application and evaluation are carried out, it can be started to determine which houses are included in the criteria for an inpatient house by bringing in guests to direct testing and evaluate their implementation.

4. In addition to the required physical readiness for a dwelling house, the home owner's readiness as a home operator has very important roles such as hospitality, politeness, the spirit of service, and tourism awareness.

5. Safety and security variables are parts that must be improved by providing training and counseling for residents who intend to make their homes into guest houses for visitors, so that guests who stay overnight will have a sense of security and comfort while staying.

6. The active role of stakeholders is required in coaching, training, and disseminate policies and regulations in providing homestay.

\section{REFERENCES}

ASEAN - Tourism. (2016). ASEAN Homestay Standard, The ASEAN Secretariat Jakarta.

Bhan, S. and Singh, L. (2014). Homestay Tourism in India: Opportunities and Challenges. African Journal of Hospitality, Tourism and Leisure, 3(2).

Chairunisa, M. (2015). Ini alasan "homestay" lebih menarik dibanding hotel. Retrieved February

25 2018, frombttp:

Tourism Research Journal, Volume 4 (2), 2020 
Analysis of Homestay Criteria Compliance in Tourist Village

According to The Visitor's Perception

//travel.kompas.com/ read/2015/09/14/092600127/Ini.Alasan.Homestay.

Lebih.MenarikDibanding.Hotel.

Festivalia, F., Enggriani, M., \& Pramanik, P. D. (2019). The Impact of Tourism on Village Society. TRJ (Tourism Research Journal), 3(2), 178-187.

Inskeep, E. (1991). Tourism Planning and Intergrated and Sustainable Development Approach, New York, Van Nostrand Reinhold. Oppermann.

Lama, M. (2013). Community homestay programmes as a form of sustainable tourism development in Nepal. Unpublished thesis. Centria University of Applied Sciences.

Antara, Made., \& Arida, I Nyoman Sukma (2015). Panduan Pengelolaan Desa

Wisata Berbasis Potensi Lokal. Konsorsium Riset Pariwisata, Universitas Udayana Bali Agustus

Nurhayati \& Wiendu. (1993). Concept, Perpective And Challenges, Makalah Bagian Dari Laporan Konfrensi Internasional Mengenai Parimisata Budaya. Yogyakarta: Gajah Mada University Press.

Rachman, A., \& Suprina, R. (2019). Pendampingan Desa Cipasung Menuju Desa Wisata. Jurnal Pemberdayaan Pariwisata, 1(1), 9 - 20.

Suprina, R., Rachman, A., \& Fitriana, R. (2019). Peningkatan Kapasitas Desa Wisata Cikolelet Melalui Program Pendampingan. Jurnal Pemberdayaan Pariwisata, 1(1), 26 - 35.

Swantari, A., \& Wicaksono, H. (2020). Development of Tourism Village in Gempol Village Karanganom District-Klaten Regency. TRJ (Tourism Research Journal), 4(1), 62-74.

Tourism Research Journal, Volume 4 (2), 2020 